ISSN : 2354-6034

IAIN Palangka Raya

\title{
WAKAF PAKAIAN PERSPEKTIF EKONOMI SYARIAH
}

\author{
Wahyu Akbar ${ }^{1}$
}

\begin{abstract}
ABSTRAK
Clothes as primary necessity is the most needed especially if there is a disaster such as flood, eruption, fire and some other disasters. It is better if the clothes belong to some unlucky people, and it can be through benefaction instrument. So it can create the economy balancing which then be able to make a development of economy equalization, especially the primary needed (daruriyat) it is about clothes needed. It can be as a solution to the overage clothes which had by the rich men and also as a way to consumptive attitude that has been a life style and character of rich men toward clothes trend mode. The main aim of this study was to review the basic problem: (1) What were the economic values which had on the clothes of syariah economy perspectives? (2) How was the clothes benefaction ijtihad of syariah economy perspectives as economy development?

This study was a library reseacrh, where specifically it was mentioned as deductive qualitative descriptive design in frame syariah ecoonomy by using histroical approach, conceptual approach, and syariah economy contextual approach, by using deductive qualitative descriptive analysis model, they were data reduction, data display, and verification. Data collected was analyzed by using retropsective method.

The results of the study concluded that: (1) the economic values which had on the clothes of syariah economy perspectives were the function value and the benefit of human sustainability guarantee which placed on priority scale of human's need. It was primary needed (daruriyat) which can guarantee the equilibrium of doing the life activity whether based on muamalah or worship. (2) the clothes benefaction ijtihad of syariah economy perspectives as economy development were through two models they were consumptives benefaction (using directly without any production process) and productive benefaction (processing the clothes which economical) as a relevant idea to the new paradigm of benefaction in Indonesia and also as solution to consumptive attitude of the community toward the dynamic of clothes trend mode.
\end{abstract}

Key words: benefaction, clothes, syariah economy

\section{A. Latar Belakang Masalah}

Fenomena yang berkembang di zaman sekarang, trend mode pakaian merupakan gaya hidup (life style) orang yang berkecukupan lebih, yakni orang-orang kaya. Dengan harta yang berlebih orang-orang kaya yang memiliki harta tersebut membelanjakan hartanya tidak sesuai kebutuhan. Akibatnya terjadi pemborosan, khususnya terhadap pakaian yang menjadi trend

\footnotetext{
${ }^{1}$ Staff Kementerian Agama Kabupaten Gunung M as.
} 
ISSN : 2354-6034

IAIN Palangka Raya

mode. Pakaian-pakaian yang tidak menjadi trend seiring dengan perubahan zaman tidak dipakai lagi, padahal banyak dari masyarakat yang miskin tidak memiliki pakaian yang layak.

Fakta sosial yang terjadi di masyarakat, orang miskin hanya mengenakan pakaian yang mungkin sudah tidak layak pakai, mengenakan satu pakaian yang dipakai terus menerus tanpa ada gantinya yang lama kelamaan nampak lusuh dan tidak layak pakai. Hal ini menunjukkan kesenjangan yang terjadi antara orang kaya yang memiliki pakaian lebih dan orang miskin yang kekurangan dan membutuhkan pakaian. Kesenjangan ini bila dibiarkan terus menerus akan membuat ketimpangan sosial dan tidak keseimbangan khususnya dalam perspektif ekonomi Islam.

Pakaian sebagai kebutuhan primer sangat dibutuhkan terlebih bila terjadi bencana alam, seperti banjir, gunung meletus, kebakaran, dan bencana lainnya. Alangkah baiknya apabila pakaian dari orang-orang kaya yang sudah tidak dipakai namun masih layak guna diberdayakan dan dimanfaatkan untuk kebutuhan masyarakat miskin. Sehingga mampu menciptakan keseimbangan ekonomi terlebih lagi mampu terjadi pemerataan dalam pembangunan ekonomi, khususnya kebutuhan primer (daruriyat) yaitu kebutuhan terhadap pakaian. Hal ini dapat menjadi solusi terhadap kelebihan pakaian yang dimiliki orang kaya dan merupakan penanggulangan perilaku konsumtif yang menjadi gaya hidup dan perilaku orang kaya terhadap trend mode pakaian.

Sebagai upaya menanggulangi perilaku konsumtif di atas, dengan meningkatnya jumlah pakaian yang sudah ketinggalan zaman atau mode pakaian yang sudah tidak menjadi trend di kalangan masyarakat yang memiliki trend gaya hidup, diperlukan suatu terobosan baru (ijtihad) yaitu dengan mendistribusikan dan mendayagunakan pakaian yang masih layak pakai atau bernilai ekonomis untuk kepentingan umat Islam dalam kebajikan (fii sabilillah). Beberapa instrumen yang dapat digunakan yaitu zakat, infaq, shadaqah dan wakaf. Menurut penulis, sangat tepat bila wakaf dijadikan sebagai instrumen pendayagunaan nilai ekonomis pakaian bagi pemberdayaan masyarakat. Sebab, yang membedakan wakaf dengan instrumen yang lain, seperti zakat, infaq, shadaqah, yaitu wakaf mampu memberikan manfaat yang berulang-ulang meskipun hanya diberikan sekali. ${ }^{2}$ Berbeda dengan zakat, infaq, dan shadaqah tidak dapat digunakan dan diberdayakan berulang-ulang. Sehingga pemanfaatan nilai ekonomis dari pakaian dapat dipergunakan secara maksimal melalui wakaf. ${ }^{3}$

\footnotetext{
${ }^{2}$ Mundzir qahf, Manajemen Wakaf Produktif, penerjemah: Muhyidin mas rida, Jakarta: Khalifa, 2005, h. 108.

${ }^{3}$ Salah satu lembaga ekonomi Islam yang sangat berperan dalam pemberdayaan ekonomi umat adalah wakaf. Menurut sejarah, wakaf telah memerankan peran penting dalam pengembangan sosial, ekonomi, dan budaya masyarakat. Hal-hal yang paling menonjol dari lembaga wakaf adalah peranannya dalam membiayai berbagai pendidikan Islam dan kesehatan. Sebagai contoh misalnya di Mesir, Saudi Arabia, Turki dan beberapa Negara lainnya pembangunan dan berbagai sarana dan prasarana pendidikan dan kesehatan dibiayai dari hasil pengembangan wakaf. Kesinambungan manfaat hasil wakaf dimungkinkan oleh berlakunya wakaf produktif yang didirikan untuk menopang berbagai kegiatan sosial dan keagamaan. Wakaf Produktif pada umumnya berupa tanah pertanian pertanian atau perkebunan, gedung-gedung komersial, dikelola sedemikian rupa sehingga mendatangkan keuntungan yang sebagian hasilnya dipergunakan untuk membiayai berbagai kegiatan tersebut. Bahkan dalam sejarah, wakaf sudah dikembangkan dalam bentuk apartemen, ruko dan lain-lain. Disamping apartemen dan ruko, terdapat wakaf toko makanan, pabrik-pabrik, dapur umum, mesin-mesin pabrik, alat-alat pembakar roti pemeras minyak, tempat pemandian, dan lain-lain. Wakaf Produktif ini kemudian dipraktekkan di berbagai Negara sampai
} 
ISSN : 2354-6034

IAIN Palangka Raya

Terkait dengan gagasan pakaian dijadikan sebagai objek wakaf sebagai bentuk penanggulangan perilaku konsumtif terhadap trend mode pakaian, Islam memberikan arahan dalam menjalankan kegiatan ekonomi agar memperhatikan faktor manfaat dan mudharat dari perilaku ekonomi dan faktor antara kepentingan pribadi dan kepentingan sosial. ${ }^{4}$ Islam menganjurkan agar harta kekayaan dapat dimanfaatkan secara maksimal. ${ }^{5}$ Maka berdasarkan hal tersebut wakaf berfungsi untuk mewujudkan manfaat ekonomis harta benda yang tidak sekedar untuk kepentingan ibadah secara konvensional, tetapi juga untuk kesejahteraan umum. ${ }^{6}$ Berdasarkan jenisnya harta yang bisa diwakafkan terdiri dari benda bergerak dan benda tidak bergerak. ${ }^{7}$ Begitu juga dengan pakaian merupakan salah satu harta manusia yang memiliki manfaat yang dikategorikan menjadi benda bergerak. Pakaian yang tidak dipakai masih bisa dirasakan manfaatnya dengan cara wakaf. Namun, pada kenyataannya wakaf yang dikenal masyarakat selain hanya wakaf tunai, juga pada benda tidak bergerak, seperti wakaf tanah dan bangunan dan atau benda tidak bergerak lainnya. ${ }^{8}$

Dari praktek pengamalan wakaf, dewasa ini tercipta suatu image atau persepsi tertentu mengenai wakaf. Pertama, objek wakaf umumnya berwujud benda tidak bergerak, khususnya tanah. Kedua, dalam kenyataannya, pengelolaan benda tidak bergerak, yaitu tanah, di atasnya didirikan masjid atau sekolah (madrasah). Ketiga, penggunaan objek wakaf didasarkan pada wasiat pemberi wakaf (wakif). ${ }^{9}$ Hal ini membentuk paradigma mengenai sistem pengelolaan wakaf, baik dari substansi (regulasi tentang wakaf), struktur (peran lembaga wakaf), dan kultur masyarakat pengelola dan yang merasakan manfaat wakaf, bahwa objek wakaf hanya mengacu pada benda tidak bergerak, padahal apabila dicermati melalui perspektif ekonomi substansi dari objek wakaf adalah nilai ekonomis yang dapat dimanfaatkan semaksimal mungkin untuk meningkatkan kesejahteraan masyarakat pada umumnya. Begitu juga dengan nilai ekonomis pakaian yang memiliki nilai guna dan manfaat, sehingga wakaf pakaian merupakan salah satu terobosan baru dalam ekonomi Islam.

Wakaf merupakan ajaran yang tidak hanya berdimensi agama, tetapi juga menekankan pentingnya kesejahteraan Sosial. ${ }^{10}$ Hal ini sejalan dengan ekonomi Islam yang berhubungan dengan kesejahteraan sosial dan juga berkaitan dengan hubungan kepada Allah. ${ }^{11}$ Namun belum adanya suatu kajian dengan kerangka ilmiah tentang nilai ekonomis pakaian yang dijadikan objek wakaf menjadikan pakaian kurang diminati untuk diberdayakan padahal jumlah pakaian

sekarang. Hasil dari pengelolaan wakaf tersebut dimanfaatkan untuk menyelesaikan berbagai masalah sosial ekonomi umat. Sumber: http://rumahwakaf.com/pemberdayaan-wakaf-produktif-untuk-pemberdayaan-ekonomiumat/, diakses pada hari Senin, Tanggal 8 Desember 2014, pukul 09.34 Wib.

${ }^{4}$ Muhammad, Ekonomi Islam, Ekonomi Islam, Malang: Empat Dua, 2009, h. 135.

${ }^{5}$ Ibid., h. 48.

${ }^{6}$ Himpunan Peraturan Perundang-Undangan Tentang Wakaf, Jakarta: Kementerian Agama Republik Indonesia Direktorat jenderal Bimbingan Masyarakat Islam Direktorat Pemberdayaan Wakaf, 2011, h. 4

${ }^{7}$ Ibid.

${ }^{8}$ Perkembangan Pengelolaan Wakaf di Indonesia, Jakarta: Direktorat Jendral Bimbingan Masyarakat Islam dan Penyelenggaraan Haji, 2003, h. 11.

${ }^{9}$ Ibid.

${ }^{10}$ Pemberdayaan Wakaf di Indonesia, Jakarta: Departemen Agama RI Direktorat Jendral Bimbingan Masyarakat Islam Direktorat Pemberdayaan Wakaf, 2008, h. 1.

${ }^{11}$ Muhammad, Prinsip-Prinsip Ekonomi Islam, yogyakarta, Graha Ilmu, 2007, h. 1-2. 
ISSN : 2354-6034

IAIN Palangka Raya

yang ada di masyarakat jumlahnya tidak sedikit, sehingga diperlukan suatu kajian yang mampu memposisikan nilai ekonomis pakaian sebagai objek wakaf dan nilai kebermanfaatan wakaf pakaian yang merupakan substansi nilai-nilai ekonomi Islam dalam kerangka ijtihad wakaf pakaiam perspektif ekonomi syariah sebagai pembangunan ekonomi.

Berdasarkan pemikiran di atas, penulis tertarik untuk mengkaji bahasan tersebut, mengenai apa nilai ekonomis yang ada pada pakaian dalam perspektif ekonomi syariah dan Bagaimana itjtihad wakaf pakaian perspektif ekonomi syariah sebagai pembangunan ekonomi.

\section{B. Deskripsi Teoritik}

1. Teori Maqashid Asy Syariah

Maqashid dalam hukum ekonomi islam maqashid membahas masalah mengenai, pengayaan agama, diri, akal, keturunan, dan harta benda sebenarnya telah menjadi fokus utama usaha semua manusia. Manusia itu sendiri menjadi tujuan sekaligus alat. Tujuan dan alat dalam pandangan al-Ghazali dan juga pra fuqaha lainnya, saling berhubungan satu sama lain dan berada dalam satu proses perputaran sebab-akibat. Realisasi tujuan memperkuat alat dan lebih jauh akan mengintensifkan realisasi tujuan. Imama al-Ghazali dan asy-Syatibi mengurutkan keimanan (agama), kehidupan, akal, keturunan, dan harta benda secara radikal berbeda dari urutan ilmu ekonomi konvensional, di mana keimanan tidak memiliki tempat, sementara kehidupan, akal, dan keturunan, sekalipun dipandang penting, hanya dianggap variabel eksogenous (di luar sistem). Karena itu, tidak mendapatkan perhatian yang memadai. ${ }^{12}$

2. Wakaf

Secara etimologis wakaf adalah bentuk mashdar (kata dasar) yang berasal dari kata ووَفَ - يَقِقْ - وَفَفا (waqafa-yaqifu-waqfan) yang memiliki arti menghentikan atau menahan

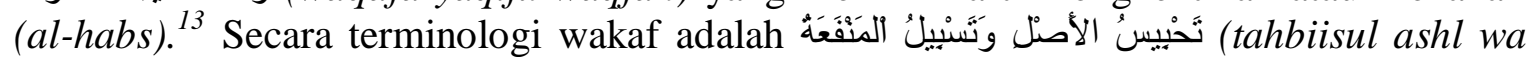
tasbiilul manfa'ah) yang berarti menahan suatu barang dan memberikan manfaat. ${ }^{14}$ Adapun menurut syariat wakaf bermakna menahan pokok dan mendermakan buah atau dengan kata lain, menahan harta dan mengalirkan manfaat-manfaatnya di jalan Allah. ${ }^{15}$

3. Wakaf sebagai Sumber Daya Ekonomi

Harta wakaf sebagai lembaga sosial Islam, pada hakikatnya dapat digunakan sebagai salah satu sumber daya ekonomi. Artinya, penggunaan harta wakaf tidak terbatas pada keperluan kegiatan-kegiatan tertentu saja berdasarkan orientasi konvensional, seperti pendidikan, masjid, rumah sakit, panti asuhan, dan lain-lain, tetapi harta wakaf dalam dalam pengertian makro dapat pula dimanfaatkan untuk kegiatan-kegiatan ekonomi. $^{16}$

${ }^{12}$ Ibid., h. 102. Lihat juga P3EI UII Yogyakarta, Ekonomi Islam., h. 7.

${ }^{13}$ Mardani, Hukum Ekonomi Syariah di Indonesia, Bandung: Refika Aditama, 2011, h. 63.

${ }^{14}$ Syaikh Muhammad bin Shalih Al-Utsaimin, Panduan Wakaf, Hibah, dan Wasiat, diterjemahkan oleh Abu Hudzaifah dari buku asli berjudul "Asy-Syarhul Mumti Kitabul Waqf wal Hibah wal Washiyyah", Jakarta: Pustaka Iman Asy-Syafi'i, 2008, h. 7.

${ }^{15}$ Sayyid Sabiq, Fiqih Sunnah Jilid 5, h. 433.

${ }^{16}$ Mardani, Hukum Ekonomi Syariah di Indonesia, h. 72. 
ISSN : 2354-6034

IAIN Palangka Raya

Pembangunan ekonomi melalui wakaf merupakan salah satu konsep ekonomi syariah yang secara islami mewujudkan kesejahteraan bagi masyarakat. Wakaf tidak hanya sekedar sebagai media kebajikan, tetapi juga sebagai instrumen sumber daya ekonomi syariah, sebab wakaf memiliki dua aspek: pertama, wujud terhadap keimanan kepada Allah dengan melakukan kebajikan dengan mengharapkan ridho-Nya, dan kedua, tanggung jawab sosial untuk kepentingan masyarakat sebagai upaya memberikan kesejahteraan untuk kepentingan bersama.

Pengelolaan wakaf sebagai sumber daya ekonomi dapat mewujudkan kesejahteraan bila dilakukan secara profesional, dalam lingkup sejarah Islam pada masa Rasulullah, wakaf merupakan isntrumen ekonomi yang mampu memberikan kesejahteraan bagi umat. Pada kondisi sekarang bila wakaf dilaksanakan dengan mengacu pada tujuan memberikan manfaat nilai ekonomis bagi kemakmuran dan pertumbuhan ekonomi, maka perlu dilakukan berbagai terobosan baru yang efektif dan efisien pada pengelolaan wakaf. Pemberdayaan potensi wakaf merupakan salah satu alternatif untuk mengatasi probem sosial. ${ }^{17}$

Konsep wakaf sebagai sumber daya ekonomi merupakan gerakan pembangunan ekonomi yang membawa pada kemaslahatan bersama, sehingga harta yang dimiliki individu kiranya dapat dipergunakan untuk kemaslahatan publik dan membawa manfaat seluas-luaasnya, sebagaimana kaidah fikih:

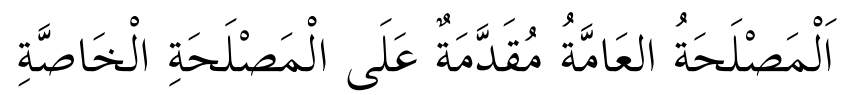

Artinya: Kemaslahatan publik didahulukan daripada kemaslahatan individu. ${ }^{18}$

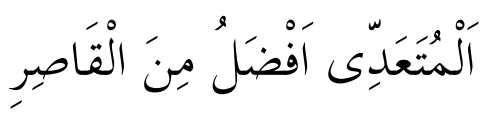

Artinya: Perbuatan yang mencakup kepentingan orang lain lebih utama daripada yang hanya terbatas untuk kepentingan sendiri. ${ }^{19}$

Berdasarkan uraian di atas, kaidah fikih tersebut menguatkan konsep wakaf sebagai sumber daya ekonomi yang membawa kepada kemaslahatan bersama sebagai pembangunan ekonomi, sehingga nilai ekonomis wakaf yang memiliki nilai guna dapat diberdayakan untuk kemakmuran bersama.

\section{Pembahasan}

1. Konsep Pakaian Perspektif Ekonomi Syariah

\footnotetext{
${ }^{17}$ Perkembangan Pengelolaan Wakaf di Indonesia, h. 87.

${ }^{18}$ A. Djazuli, Kaidah-kaidah Fikih: Kaidah-kaidah Hukum Islam dalam Menyelesaikan Masalah-masalah yang Praktis, Jakarta: Kencana, 2007, h. 11.

${ }^{19}$ Musbikin, Imam, Qawa'id al-fiqhiyah, Jakarta: PT. RajaGrafindo Persada, 2001, h. 150-151.
} 
ISSN : 2354-6034

IAIN Palangka Raya

Harta meliputi segala sesuatu yang digunakan manusia dalam kehidupan sehari-hari (duniawi) seperti uang, tanah, kendaraan, rumah, perhiasan, perabotan rumah tangga, hasil perkebunan, hasil perikan-lautan, dan pakaian termasuk dalam kategori al amwal. Islam sebagai agama yang benar dan sempurna memandang harta tidak lebih dari sekedar anugerah Allah swt yang dititipkan kepada manusia. Oleh karena itu, di dalam Islam terdapat etika di dalam memperoleh harta dengan bekerja. Dalam artian, terdapat keseimbangan usaha manusia dalam mendapatkan materi agar sesuai dengan harapan yang dicita-citakan sebagai khalifah di bumi.

Harta adalah sesuatu yang dibutuhkan dan di peroleh manusia,baik berupa benda yang tampak seperti mas perak maupun yang tidak tampak yakni manfaat seperti pakaian,tempat tinggal. Sehingga persoalan harta dimasukkan kedalam salah satu lima keperluan pokok yang diatur oleh Alquran dan sunah. Adapun fungsi harta diantaranya kesempurnaan ibadah mahdzah, memelihara dan meningkatkan keimanan dan serta menyelaraskan antara kehidupan dunia dan akhirat. Sedangkan pembagian harta di bagi menjadi delapan bagian.

Dari penjelasan di atas, pakaian merupakan salah satu harta yang dibutuhkan dan menempati posisi utama sebagai kebutuhan primer (daruriyat). Ekonomi syariah sangat menekankan seseorang untuk memiliki kekayaan. Kekayaan yang dimaksud dalam pernyataan ini adalah kondisi kelebihan harta dimana si pemiliknya memiliki harta lebih dari cukup untuk kebutuhannya secara wajar. Kaya adalah lawan dari kata miskin yaitu kondisi kekurangan harta untuk memenuhi kebutuhan yang layak dimiliki. Dengan demikian seseorang dikatakan kaya apabila dalam kehidupan sehari-hari, ia memiliki kelebihan harta setelah segala kebutuhannya dalam batas wajar tercukupi.

Pakaian dalam perspektif ekonomi syariah merupakan bagian harta kekayaan berupa karunia dan kebaikan yang dipergunakan untuk kepentingan dunia dan akhirat dalam melaksanakan kehidupan seorang manusia dan hamba Allah SWT.

2. Wakaf Sebagai Instrumen Pembangunan Ekonomi

Untuk menjamin kelanggengan harta wakaf agar dapat terus memberikan pelayanan prima sesuai dengan tujuannya, diperlukan dana-pemeliharaan di atas baiayabiaya yang telah dikeluarkan. Hal ini berlaku pada proyek penyedia jasa maupun proyek hasil pendapatan. Sehingga dengan demikian, pada proyek penyedia jasa pun diperlukan pensyaratan menghasilkan pendapatan untuk menutup biaya pemeliharaan. Berdasarkan konteks wakaf, maka pembiayaan proyek wakaf bertujuan untuk mengoptimalkan fungsi harta wakaf sebagai prasarana untuk meningkatkan kualitas hidup dan kehidupan sumber daya insani.

Menurut Monzer Kahf, gagasan menyisihkan sebagian pendapatan wakaf untuk mengkonstruksi harta tetap wakaf tidak dibahas dalam fikih klasik. Oleh karena itu Kahf membedakan pembiayaan proyek wakaf ke dalam model pembiayaan harta wakaf tradisional dan model pembiayaan baru harta wakaf secara institusional. ${ }^{20}$ Instrumen yang ditawarkan Islam ini merupakan perwujudan dari aspek moral yang menekankan kepada nilai keadilan, yang menjadi ajaran dasar yang terdapat di dalam Alquran, dan

\footnotetext{
${ }^{20}$ Munzir Qahaf, Manajemen Wakaf Produktif, Jakarta: Khalifa, 2005, h. 17.
} 
ISSN : 2354-6034

IAIN Palangka Raya

salah satu bentuknya adalah terlihat pada keadilan sosial ekonomi. Konsep keadilan sosial ekonomi dalam perspektif Islam didasarkan pada ajaran persaudaraan yang melampaui batas-batas geografis, suku, agama, dan ras. Hal ini dapat menciptakan hubungan antara sesama manusia hidup berdampingan secara damai dan bersahabat, walaupun memiliki perbedaan yang cukup mendasar. Tentunya ini dapat diartikan sebagai bentuk dari universalitas Islam sebagai rahmat bagi semua orang/umat (rahmatan lil 'alamin).

Keadilan sosial ekonomi (economic social justice) mengandung pengertian bahwa Islam sangat menekankan persamaan manusia (egalitarianisme) dan menghindarkan segala bentuk kepincangan sosial yang berpangkal dari kepincangan ekonomi, seperti eksploitasi, keserakahan, konsentrasi harta pada segelintir orang dan lain-lain.

Terciptanya keadilan sosial ekonomi akan dapat menghindarkan manusia dari kesenjangan-kesenjangan diantara sesamanya, salah satunya adalah kesenjangan pendapatan dalam masyarakat. Tentunya ini berlawanan dengan semangat serta komitmen Islam terhadap persaudaraan. Kesenjangan harus diatasi dengan menggunakan cara yang ditekankan Islam. Keadilan dalam Islam dapat tercipta diantaranya adalah dengan:

a. Menghapuskan monopoli, kecuali oleh pemerintah untuk bidang-bidang tertentu.

b. Menjamin hak dan kesempatan kepada semua pihak untuk aktif dalam proses ekonomi, baik produksi, distribusi, sirkulasi maupun konsumsi.

c. Menjamin pemenuhan kebutuhan dasar hidup (basic needs fulfillment) setiap anggota masyarakat.

d. Melaksanakan al-takaful al-ijtima' (social economic security insurance) di mana yang mampu menanggung dan membantu yang tidak mampu.

Dengan cara ini diharapkan, standar kehidupan setiap individu akan lebih terjamin.

Sisi manusiawi dan kehormatan setiap individu akan lebih terjaga sesuai dengan harkat dan mertabat yang telah melekat pada manusia sebagai khalifah Allah di muka bumi. Namun, tidak dapat di sangkal bahwa perbedaan dalam pendapatan harta (kekayaan) merupakan sesuatu yang wajar, yang dapat terjadi di setiap masyarakat. Antara individu satu dengan yang lain tidak harus memiliki kesamaan atau secara merata sama harta kekayaannya. Inilah yang membolehkan adanya kekayaan pribadi dan inisiatif individual dalam semua aktivitas kehidupan. Islam tidak mengekang kebebasan individu untuk pencapaian keinginan pribadinya dan membolehkan kepemilikan pribadi, tetapi tidak menciptakan golongan miskin ke dalam jurang pemisah dengan golongan kaya tanpa tiada dijembatani, hal ini akan berakibat kepada kecemburuan sosial di masyarakat. Islam menjaga ketidakmerataan ekonomi kedalam batas-batas yang alami dan wajar. Dibolehkannya pemilikan pribadi dan ketidakmerataan ekonomi masih dalam batas-batas yang adil dalam masyarakat. Ini dimaksudkan untuk menyediakan kesempatan bagi individu untuk mengembangkan dan memanfaatkan kualitas kemuliaan dirinya.

Wakaf sebagai salah satu instrumen ibadah tabarru, harus diberikan porsi yang sama banyak sebagimana ibadah zakat. Apalagi wakaf (shadaqah jariah) yang dijanjikan oleh Allah swt. memiliki bobot pahala yang terus mengalir, walaupun para pelaku (wakif) sudah meninggal dunia. Untuk itu pahala pendekatan keagamaan perlu digiatkan oleh 
ISSN : 2354-6034

IAIN Palangka Raya

para agamawan kepada umat Islam yang memiliki kemampuan finansial agar mau mewakafkan sebagian hartanya. Bagaimana bentuk pendekatannya tentu saja dibutuhkan kearifan dan metode yang tepat sehingga lebih menyentuh kepada para calon wakif seperti keteladanan dan amanah.

Peran wakaf merupakan salah satu sumber dana yang penting yang besar sekali manfaatnya bagi kepentingan agama dan umat. Di antaranya adalah untuk pembinaan kehidupan beragama dan peningkatan kesejahteraan umat Islam, terutama bagi orangorang yang tidak mampu, cacat mental/fisik, orang-orang yang sudah lanjut usia dan sebagainya yang sangat memerlukan bantuan dari sumber dana seperti wakaf itu. Mengingat besarnya manfaat wakaf itu, maka Nabi sendiri dan para sahabat dengan ikhlas mewakafkan masjid, tanah, sumur, kebun dan kuda milik mereka pribadi.

3. Manajemen Wakaf dalam Ekonomi Syariah

Perkembangan manajemen harta wakaf selama beberapa tahun tidak diragukan lagi, secara keseluruhan merupakan upaya perbaikan yang bertujuan memperbaiki manajemen wakaf. Upaya perbaikan ini pada hakekatnya merupakan perubahan pada bentuk dan sistem kepengurusan baru yang sesuai dengan karakteristik wakaf Islam. Hal ini karena ia sebagai bagian dari lembaga ekonomi ketiga yang erat kaitannya dengan pembangunan masyarakat dan bukan dengan pemerintah. Karena itu, untuk menentukan bentuk manajemen yang diinginkan bagi wakaf, pertama kali harus mengenal secara detil tujuantujuan yang menurut pengurus wakaf dapat diperkirakan dan dapat direalisasikan.

Manajemen wakaf memberikan pembinaan dan pelayanan terhadap sejumlah harta yang dikhususkan untuk merealisasikan tujuan tertentu. Karena itu, usahanya harus terkonsentrasi pada upaya merealisasikan sebesar mungkin perolehan manfaat untuk tujuan yang telah ditentukan pada harta tersebut. Untuk itu, target manajemen wakaf adalah sebagai berikut:

a. Meningkatkan kelayakan produksi harta wakaf hingga mencapai target ideal untuk memberi manfaat sebesar mungkin bagi tujuan wakaf.

b. Melindungi pokok-pokok harta wakaf dengan mengadakan pemeliharaan dan penjagaan yang baik dalam menginvestasikan harta wakaf dan mengurangi sekecil mungkin resiko investasi. Sebab harta wakaf merupakan sumber dana abadi yang hasilnya disalurkan untuk berbagai tujuan kebaikan.

c. Melaksanakan tugas distribusi hasil wakaf dengan baik kepada tujuan wakaf yang telah ditentukan, baik berdasarkan pernyataan wakif dalam akte wakaf maupun berdasarkan pendapat fikih dalam kondisi wakaf hilang aktenya dan tidak diketahui tujuannya, dan mengurangi kemungkinan adanya penyimpangan dalam menyalurkan hasil-hasil tersebut.

d. Berpegang teguh pada syarat-syarat wakif, baik itu berkenaan dengan jenis investasi dan tujuannya maupun dengan tujuan wakaf, pengenalan objeknya dan batasan tempatnya, atau bentuk kepengurusan dan seluk-beluk cara nazhir bisa menduduki posisi tersebut.

e. Memberikan penjelasan kepada para dermawan dan mendorong mereka untuk melakukan wakaf baru, dan secara umum memberi penyuluhan dan menyarankan pembentukan wakaf baru baik secara lisan maupun dengan cara memberi keteladanan. 
Pengelolaan wakaf yang dikelola dengan sistem dan manajemen yang amanah dan profesional, dengan bimbingan dan pengawasan dari Pemerintah, yang dalam operasionalisasinya terintegrasi sampai tingkat daerah akan memacu gerak ekonomi di dalam masyarakat dan sekaligus menyehatkan tatanan sosial dengan makin berkurangnya kesenjangan antara kelompok masyarakat yang mampu dan masyarakat yang tidak mampu.

4. Inovasi Wakaf dalam Ekonomi Syariah

Sejarah wakaf produktif dimulai sejak Rasulullah Saw. menasehati Umar ra. untuk membentuk wakaf baru di Khaibar. Demikian juga isyarat Rasulullah untuk membeli sumur Raumah yang dilakukan oleh Utsman ra. berdasarkan isyarat Rasulullah tersebut. Jadi jelas bahwa perkembangan wakaf Islam sepanjang sejarah tidak selamanya karena adanya lembaga wakaf yang secara khusus mendorong pembentukannya. Sebab pada zaman dulu lembaga wakaf seperti ini belum ada. Oleh karena itu, tujuan mendorong terbentuknya wakaf baru terikat dengan pemerintah-pemerintah yang ada saat ini, terutama secara khusus dengan Kementerian Wakaf atau Departemen Agama, Departemen Sosial, dan Departemen Pendidikan. Peranan pengurus harta wakaf produktif terbatas pada memberikan pandangan untuk mendorong para wakif baru. Karena itu, Mundzir Qahaf menegaskan bahwa pengurus harta wakaf produktif hanya membantu memberikan saran dan mengajak para dermawan untuk membentuk wakaf baru. Barangkali yang perlu ditambahkan di sini bahwa pengurus wakaf menyalurkan sebagian hasil wakaf untuk mendorong terbentuknya wakaf baru, apabila itu masuk ke dalam syarat wakif. Misalnya membuat tujuannya secara umum untuk menyebarkan ilmu syariat dan dakwah serta semua bentuk kebaikan pada umumnya. Walaupun demikian, seseorang tidak boleh mengambil kesimpulan bahwa adanya lembaga penerangan dan pengarahan wakaf tidak ada manfaatnya, karena hal itu justru menjadi sangat penting pada zaman dimana spesialisasi menjadi syarat kelayakan dalam merealisasikan tujuan wakaf, dan dengan berkembangnya alat penerangan dan bentuknya. Akan tetapi yang perlu diketahui adalah bahwa tujuan ini terikat dengan pemerintah saat ini, kementeriannya dan kelembagaannya, dan tidak terbatas pada lembaga wakaf saja, terutama karena secara syariat tidak dikenal penyisihan sebagian hasil wakaf untuk membangun wakaf baru kecuali hal itu ada dalam syarat wakif. Seperti kalau wakif menyebutkan untuk menyebarkan ilmu syariat, dakwah dan semua tujuan kebaikan secara umum dalam tujuan wakafnya.

Tujuan menyebarkan penyuluhan wakaf dan membentuk wakaf baru, dianggap sebagai urusan sampingan bagi pengurus wakaf produktif. Akan tetapi yang diinginkan dari memasukkan tujuan ini ke dalam tujuan kepengurusan wakaf agar pembahasannya tidak terbatas pada pengurusan harta wakaf produktif semata, melainkan meliputi gambaran yang lebih dekat dan lebih ideal, dilihat dari syarat wakif dan tujuan syariat, karena peran kementerian wakaf itu sendiri dan lembaga pemerintah yang mengendalikan urusan wakaf, baik yang disebut badan wakaf ataupun lembaga wakaf, di pusat maupun di daerah.

Kebanyakan wakaf yang ada di dunia Islam tidak pernah terbetik pada wakifnya bahwa yang mengelolanya adalah Kementerian Wakaf dan semua perangkatnya baik di 
pusat maupun di daerah, baik secara tertulis maupun isyarat dari wakif. Hal itu dikarenakan alasan yang sangat sederhana, yaitu Kementerian Wakaf atau perangkatnya belum ada pada zaman dulu ketika wakaf dibentuk, dan tidak pernah terbetik dalam diri wakif bahwa akan ada hal itu di masa mendatang. Akan tetapi ini bukan berarti tidak mungkin wakaf baru itu berdiri, dimana ia membuat syarat agar yang menjadi nazhirnya adalah pemerintah, seperti Kementerian Wakaf atau perangkatnya. Kewajiban adanya pihak swasta yang mengelola wakaf adalah salah satu kewajiban yang sejalan dengan syarat-syarat para wakif atas dasar perbandingan yang ada pada akte dan dokumen wakaf serta pertanyaan dan fatwa fikih yang bisa kita temukan di banyak buku-buku fikih, terutama karena adanya banyak penyimpangan dalam pengelolaan wakaf oleh pemerintah, demikian terhadap hukum-hukum fikih yang berkenaan dengan pemilihan nazhir atau wali wakaf dalam keadaan tidak ditentukan oleh wakif atau karena kematian wakif dan tidak adanya pernyataan tentang cara pemilihannya setelah kematiannya. Kepengurusan swasta yang kita maksudkan adalah pengelolaan setiap harta wakaf yang dilakukan secara tersendiri tanpa disatukan dengan harta wakaf yang lain dan tanpa adanya kepengurusan dengan sistem sentralisasi yang dalam mengambil keputusannya berkenaan dengan pengembangan harta wakaf produktif yang tergantung kepada pusat. Kepengurusan swasta ini juga mengandung pengertian bahwa setiap harta wakaf mempunyai manajer tersendiri dimana ia bisa hanya bekerja untuk wakaf, atau bisa saja menjadi manajer yang tidak sepenuhnya bekerja pada wakaf, baik hal itu dikarenakan ukuran wakaf atau karakteristik harta produktif yang diwakafkan atau bentuk investasi yang ditentukan untuk pengembangan harta wakaf tersebut. Manajer wakaf biasanya berasal dari penduduk setempat, dimana wakaf berada atau orang yang punya hubungan erat dengan tujuan wakaf dan orang-orang yang berhak atas manfaatnya.

Pengelolaan ini pada hakekatnya merupakan pengelolaan wakaf secara tradisional yang pelaksanaannya berlangsung dalam kurun waktu yang sangat lama. Justru latar belakang kesuksesan wakaf Islam dalam sejarah di berbagai bidang, terutama di bidang pendidikan dan kesehatan, penelitian ilmiah dan pelayanan masyarakat, adalah karena semua wakaf Islam berdiri secara independen, layak dan fleksibel dalam menerapkan sistem manajemen wakaf setiap hari dan setiap tahunnya. Akan tetapi bentuk pengelolaan seperti itu juga yang mendapat banyak kritikan sehingga berdiri Kementerian Wakaf dan terbentuknya perangkat pemerintah lainnya dalam mengelola wakaf sejak pertengahan abad ke-19 hingga sekarang. Ide reformasi pada manajemen harta wakaf yang di belakangnya ada campur tangan negara dalam kepengurusan wakaf memiliki berbagai kebebasan sosial. Barangkali yang paling tepat untuk menyatakan hal ini adalah seperti yang dikatakan Ibnu Abidin yang hidup pada zaman itu. "Sebenarnya kerusakan itu bukan saja timbul dari para wali wakaf, tapi juga perangkat pengadilan yang mengawasi wakaf, terlebih lagi karena rusaknya lembaga pemerintahan." Mungkin dengan pernyataan ini, Ibnu Abidin ingin mengusulkan dibentuknya kembali kepengurusan wakaf dalam bentuk yayasan yang nazhirnya dipilih oleh pengurus secara kolektif terlepas dari unsur kesukuan dalam mengoptimalkan pelaksanaan kepengurusan internal yang dibentuk oleh pengurus. Upaya reformasi dalam memanajemen wakaf belum memberi kesempatan untuk perbaikan yang sebenarnya dalam bentuk yayasan yang dapat 
menyebabkan kelayakan produksi dan dalam menjaga pokok harta wakaf serta kelayakan dalam penyaluran hasil-hasilnya kepada tujuan wakaf disebabkan oleh bentuk campur tangan yang berasal dari pemerintah dalam melakukan reformasi wakaf. Jadi dalam kepengurusan swasta tidak terjadi kerusakan, karena bersifat lokal dan independen hingga pemerintah menggantinya dengan kepengurusan sistem sentralisasi. Maka jelas kerusakan itu timbul karena tidak adanya bentuk yayasan yang dapat menerapkan kelenturan dan kelayakan dalam memanaj wakaf dengan tingkat ketaatan yang sangat tinggi terhadap badan pengawas dalam bentuk yang punya keterikatan dengan terealisasinya tujuan wakaf produktif.

Bentuk manajemen wakaf produktif yang diinginkan baik secara konsep, harta maupun tujuan, hendaknya dapat merealisasikan tujuan yang pertama melalui terbentuknya yayasan yang dikelola oleh pihak swasta setempat dan tidak mengorbankan syarat mereka dalam mengelola wakaf, baik itu disebutkan secara terang-terangan dalam akte wakaf ataupun secara isyarat dari karakteristik kegiatan wakaf dan periode sejarah yang tumbuh. Sedangkan tujuan kedua bagi wakaf produktif, yaitu meningkatkan kelayakan produksi dengan memperbesar hasil wakaf dan menekan pengeluaran administrasi dan investasi, melindungi pokok harta wakaf, serta mengurangi kerusakan dalam administrasi dan distribusi hasil-hasilnya. Kita barangkali perlu membicarakan minimnya kelayakan kepengurusan dari pihak pemerintah pada umumnya dalam investasi harta wakaf yang bertujuan meningkatkan keuntungan. Sebenarnya perubahan yang diinginkan dalam bentuk kepengurusan harta wakaf produktif adalah bentuk kepengurusan yayasan yang terlepas dari campur tangan pemerintah dan menjaga statusnya sebagai lembaga ekonomi ketiga, dan tidak juga masuk pada kepengurusan pihak swasta penuh pada waktu yang bersamaan. Masalah yang mempunyai aspek lain juga yaitu bahwa kepengurusan harta wakaf tidak dapat dipaksakan mengikuti prinsip ekonomi pasar, sebab tidak ada kesesuaian dengan moralitas ekonomi dan produktivitas pasar, yang selalu memegang prinsip keuntungan.

Pemahaman dan pemberdayaan harta wakaf di kalangan umat Islam telah mengalami perubahan yang signifikan. Dari waktu ke waktu, pemahaman wakaf produktif pun semakin berkembang dan komprehensif yang bertujuan untuk mengembangkan ekonomi, untuk kepentingan sosial masyarakat. Karena itu, umat Islam telah menemukan wajah ekonomi baru yang muncul dari wakaf, yaitu dengan cara mendirikan yayasan atau lembaga pengembangan ekonomi berorientasi pada pelayanan masyarakat. Ini menunjukkan betapa pentingnya pemberdayaan harta wakaf produktif untuk meningkatkan ekonomi umat.

Semakin luasnya pemahaman dan pemberdayaan harta wakaf ini sangat penting, terutama jika dikaitkan dengan konsep pengembangan wakaf produktif dalam meningkatkan perekonomian umat. Bahkan sebagian besar lembaga sosial yang berdiri saat ini dananya ditopang dari wakaf dan bergerak dalam bidang pengelolaan wakaf secara produktif dalam rangka memberikan pembinaan dan perlindungan kepada masyarakat, seperti yayasan yatim piatu, lembaga perlindungan anak-anak, lembaga pendidikan, lembaga kesehatan, penyaluran air bersih ke seluruh kota dan berbagai kegiatan sosial lainnya. Peran pengelola wakaf pun semakin luas, tidak hanya sekedar 
ISSN : 2354-6034

IAIN Palangka Raya

menjaga dan melakukan hal-hal yang bersifat rutinitas, melainkan juga mencari inovasiinovasi baru dalam rangka mengembangkan dan memberdayakan aset wakaf tersebut.

5. Konsep Wakaf dalam Ekonomi Syariah

Wakaf dalam ekonomi syariah adalah sebagai insturmen pembangunan ekonomi yang bertujuan kepada orientasi kesejahteraan di dunia dan kesejahteraan di akhirat (falah). Melalui instrumen eskonomi syariah berupa wakaf yaitu dengan memberdayakan dan memanfaatkan nilai ekonomis dari kemanfaatan dan kegunaan benda wakaf yang dapat memenuhi kebutuhan masyarakat pada umumnya merupakan suatu konsep pembangunan ekonomi masyarakat yang bernilai ibadah dan juga sosial. Sebab, para ulama mengkategorikan wakaf sebagai amal ibadah shadaqah jariyyah yang memiliki nilai pahala yang terus mengalir walaupun yang melakukannya telah meninggal dunia. Tentu saja, dalam pandangan yang paling sederhana sekalipun, bahwa kontinuitas pahala yang dimaksud karena terkait dengan aspek kemanfaatan yang bisa diambil manfaatnya secara berkesinambungan oleh kepentingan dan kemaslahatan masyarakat banyak (kebajikan).

Adapun kriteria yang dapat dijadikan sebagai benda wakaf (shadaqah jariyyah) yang mendapatkan nilai pahala yang terus mengalir karena kemanfaatannya, yaitu:

a. Benda yang dapat dimanfaatkan (digunakan) oleh orang banyak. Dengan kehadiran benda wakaf yang memiliki nilai manfaat atau nilai guna, maka paradigma baru wakaf harus didasari aspek tersebut, sehingga jika ada benda yang memiliki nilai manfaat atau nilai guna yang kecil atau tidak sama sekali, maka sudah selayaknya benda tersebut diberdayakan dan dikelola secara profesional dan produktif dalam rangka meningkatkan nilai fungsi yang berdimensi ibadah dan sosial. ${ }^{21}$

b. Benda yang memberikan nilai yang nyata kepada wakif. Karena sifanya memberi manfaat kepada orang lain, maka wakif pun akan merasa puas secara batin. Dan rasa batin tersebut akan seara otomatis dapat mendorong meningkatnya kualitas syukur kepada Allah SWT yang berbentuk ibadah lainnya. ${ }^{22}$

c. Manfaat material benda wakaf melebihi manfaat materialnya. Karena benda wakaf itu sendiri yang menjadi nilainya adalah manfaat dan fungsi benda wakaf tersebut untuk kepentingan dan kemaslahatan masyarakat banyak daripada benda wakaf itu sendiri. ${ }^{23}$

d. Benda wakaf tidak menjadikan atau memudharatkan orang lain atau wakif sendiri. Oleh sebab itu, benda wakaf harus yang memberikan manfaat bukan mendatangkan mudharat. $^{24}$

Berdasarkan kemanfaatan dan kegunaan benda wakaf maka dapat disimpulkan bahwa, benda wakaf memiliki nilai ekonomis yang dapat dijadikan sebagai alat pemenuhan ekonomi dalam konteks ekonomi syariah. Maka konsep wakaf dalam ekonomi syariah adalah pemberdayaan dan pengelolaan benda wakaf agar dimanfaatkan

\footnotetext{
${ }^{21}$ Direktorat Pemberdayaan Wakaf, Paradigma Baru Wakaf di Indonesia, Jakarta: Direktorat Jenderal Bimbingan Masyarakat Islam Departemen Agama RI, 2008, h. 72-73.

${ }^{22}$ Ibid., h. 74.

${ }^{23}$ Ibid.

${ }^{24}$ Ibid., h. 75 .
} 
ISSN : 2354-6034

IAIN Palangka Raya

dan digunakan untuk menyejahterakan masyarakat secara luas dan berkesinambungan, baik melalui aktivitas produksi, distribusi, dan konsumsi untuk kemaslahatan masyarakat dan pembangunan ekonomi. Dengan kata lain wakaf dalam ekonomi syariah adalah investasi abadi di dunia dan akhirat.

\section{Penutup} berikut:

Berdasarkan penelitian yang telah dilakukan penulis, maka dapat disimpulkan sebagai

1. Nilai ekonomis pakaian perspektif ekonomi syariah adalah nilai guna dan manfaat dalam menjamin keberlangsungan hidup manusia yang menduduki skala prioritas kebutuhan manusia yaitu kebutuhan primer (daruriyat) yang dapat menjamin keseimbangan (equilibrium) dalam melakukan aktivitas hidup baik secara muamalah maupun ibadah. Nilai ekonomis pakaian yaitu kegunaan dan kemanfaatan yang dapat bernilai dalam memenuhi kebutuhan hidup manusia, sehingga nilai ekonomis pakaian perspektif ekonomi syariah adalah nilai guna dan manfaat bagi kemaslahatan manusia dalam memenuhi kebutuhan.

2. Ijtihad wakaf pakaian perspektif ekonomi syariah sebagai pembangunan ekonomi ialah melalui dua model yaitu wakaf konsumtif (digunakan secara langsung) dan wakaf produktif (mengolah pakaian yang bernilai ekonomis) merupakan gagasan yang relevan dijadikan sebagai paradigma baru wakaf di Indonesia dan juga sebagai solusi perilaku konsumtif mayarakat terhadap dinamika trend mode pakaian. Melalui wakaf pakaian diharapkan bagi seluruh lapisan masyarakat dapat berwakaf, sebab pastinya setiap orang yang berpakaian dapat mewakafkan pakaiannya. Di samping itu juga dapat membuka peluang baru gerakan wakaf pakaian yang aplikatif, efektif, inovatif, transformatif, dan sederhana sehingga diharapkan semua masyarakat untuk turut berpartisipasi mewakafkan pakaian (menjadi muwakif).

\section{DAFTAR PUSTAKA}

A. Djazuli, Kaidah-kaidah Fikih: Kaidah-kaidah Hukum Islam dalam Menyelesaikan Masalahmasalah yang Praktis, Jakarta: Kencana, 2007.

Direktorat Pemberdayaan Wakaf, Paradigma Baru Wakaf di Indonesia, Jakarta: Direktorat Jenderal Bimbingan Masyarakat Islam Departemen Agama RI, 2008.

Himpunan Peraturan Perundang-Undangan Tentang Wakaf, Jakarta: Kementerian Agama Republik Indonesia Direktorat jenderal Bimbingan Masyarakat Islam Direktorat Pemberdayaan Wakaf, 2011.

Http://rumahwakaf.com/pemberdayaan-wakaf-produktif-untuk-pemberdayaan-ekonomi-umat/, diakses pada hari Senin, Tanggal 8 Desember 2014, pukul 09.34 Wib.

Mardani, Hukum Ekonomi Syariah di Indonesia, Bandung: Refika Aditama, 2011.

Muhammad, Ekonomi Islam, Ekonomi Islam, Malang: Empat Dua, 2009.

Muhammad, Prinsip-Prinsip Ekonomi Islam, yogyakarta, Graha Ilmu, 2007.

Musbikin, Imam, Qawa'id al-fiqhiyah, Jakarta: PT. RajaGrafindo Persada, 2001. 
ISSN : 2354-6034

IAIN Palangka Raya

P3EI UII Yogyakarta, Ekonomi Islam, Jakarta: Rajawali Press, 2012.

Pemberdayaan Wakaf di Indonesia, Jakarta: Departemen Agama RI Direktorat Jendral Bimbingan Masyarakat Islam Direktorat Pemberdayaan Wakaf, 2008.

Perkembangan Pengelolaan Wakaf di Indonesia, Jakarta: Direktorat Jendral Bimbingan Masyarakat Islam dan Penyelenggaraan Haji, 2003.

Qahf, Mundzir, Manajemen Wakaf Produktif, penerjemah: Muhyidin mas rida, Jakarta: Khalifa, 2005.

Sabiq, Sayyid, Fiqih Sunnah Jilid 5, diterjemahkan oleh Abu Syauqina dan Abu Aulia Rahma dari buku asli berjudul "Fiqhus Sunnah", Jakarta: Tinta Abadi Gemilang, 2013.

Syaikh Muhammad bin Shalih Al-Utsaimin, Panduan Wakaf, Hibah, dan Wasiat, diterjemahkan oleh Abu Hudzaifah dari buku asli berjudul "Asy-Syarhul Mumti Kitabul Waqf wal Hibah wal Washiyyah”, Jakarta: Pustaka Iman Asy-Syafi'i, 2008. 